\title{
Innovative Process to Eliminate Ledeburite Network in Tool Steel
}

\section{Kateřina Rubešová, Michal Peković, Hana Jirková}

Faculty of Mechanical Engineering - Regional technological institute, Univerzity of West Bohemia, Univerzitní 8, 306 14 Pilsen, Czech Republic.E-mail: krubesov@rti.zcu.cz, pekovicm@rti.zcu.cz, hstankov@vctt.zcu.cz

Tool steels are a widely-used material with well-known heat treatment procedures for obtaining the desired mechanical properties. Their weakness is the presence of sharp-edged carbides which compromise the material's toughness. When produced by conventional metallurgical routes, high-alloy steels, such as X210Cr12 (1.2080) and X155CrVMo121, contain sharp-edged M7C3 carbides which remain stable even at high temperatures. As these carbides form as early as in the solidification stage, there is no practical conventional heat treatment for removing them or for converting them to more favourable carbide types. As a result, unconventional methods must be sought for these steels. One of them combines short-time conversion to semi-solid state and subsequent thermomechanical treatment. This method was used with both tool steels named above, with a great emphasis on the choice of the heating temperature. The results showed that at an appropriate heating temperature and deformation magnitude, very fine structure can be obtained in which the matrix consists of grains of the M-A constituent and carbide precipitates. In X210Cr12 steel, hardness values of up to 862 HV10 were achieved. In X155CrVMo121, the hardness level was 859 HV10.

Keywords: semi-solid treatment, tool steels, $\mathrm{X} 210 \mathrm{Cr} 12$, chromium carbides, thermo-mechanical treatment, refinement of carbides

\section{Acknowledgement}

The present contribution has been prepared under project LO1502 'Development of the Regional Technological Institute' under the auspices of the National Sustainability Programme I of the Ministry of Education of the Czech Republic aimed to support research, experimental development and innovation.

\section{References}

[1] AIŠMAN, D., OPATOVÁ, K., RUBEŠOVÁ, K., JENÍČEK, Š. (2016). Unconventional methods of thermomechanical treatment of tool steel. Manufacturing Technology, 2016, roč. 16, č. 6, s. 1226-1230. ISSN: 1213-2489

[2] FLEMING, M.C. (1991). Behavior of Metal Alloys in the Semisolid State. 1991, Metall Trans A, 22: $957-981$.

[3] HIRT, G., KOPP, R. (2009). Thixoforming: Semi-solid Metal Processing. WILEY-VCH Verlag GmbH \& Co. KGaA, Weinheim, Copyright 2009. pp 1 - 27. ISBN: 978-3-527-3220 4-6.

[4] AIŠMAN, D., JIRKOVÁ, H., RUBEŠOVÁ, K., JENÍČEK, Š. (2016). Mini-Thixoforming of Low-Carbon HighAlloy Steel. Manufacturing Technology, 2016, roč. 16, č. 5, s. 845-849. ISSN: 1213-2489R

[5] JIRKOVÁ, H., AIŠMAN, D., MAŠEK, B. (2010). Unconventional structure of X210Cr12 steel obtained by thixoforming. Journal of Alloys and Compounds, 2010. 504 S500-S3.

[6] RONEŠOVÁ, A., MAŠEK, B., STAŇKOVÁ, H., ŠTÁDLER, C. (2008). Method of handling and its shaping at a temperature between solid and liquid, Patent CZ, 3. 10. 2008. c. 299758.

[7] JMatPro, Release 9.0, Sente Software Ltd., 2016 